\title{
Powder for Solution for Injection/Infusion Dosage Form
}

National Cancer Institute

\section{Source}

National Cancer Institute. Powder for Solution for Injection/Infusion Dosage Form. NCI

Thesaurus. Code C149848.

Solid sterile preparation consisting of one or more powders intended to be dissolved in the specified liquid to obtain a solution for injection/infusion. 